\title{
PENGARUH DESENTRALISASI FISKAL TERHADAP PERTUMBUHAN EKONOMI DAERAH DI INDONESIA, 2008 - 2012
}

\author{
Abdillah Khamdana \\ Program Magister Ekonomika Pembangunan, \\ Fakultas Ekonomika dan Bisnis, Universitas Gadjah Mada \\ Alamat Korespondensi: kamandana@gmail.com
}

\section{INFORMASI ARTIKEL}

Diterima Pertama

24 Mei 2016

Dinyatakan Diterima

15 Juli 2016

KATA KUNCI:

Fiscal Policy, Fiscal

Decentralization, Economic Growth, Regional Inflation

Rate, Local Government Expenditure, Local Government Revenue.

KLASIFIKASI JEL:

E6, H3, H5, 01, R5

\begin{abstract}
ABSTRAK
This study aims to analyze the effect of fiscal decentralization on the economic growth in Indonesian provinces. The analysis of fiscal decentralization used three indicators, i.e. revenue, expenditure, and autonomy, added by control variables that consists of population growth, ratio of domestic investment to GDP, and regional inflation rate. This study used panel data of 33 provinces in Indonesia from the period of 2008-2012 with Random Effect Model (REM) method. The results show that fiscal decentralization has been proven not significantly increase the economic growth of the provinces. Therefore, reconsidering fiscal policy related to regional planning and budgeting, and determining development priority scale are needed. Consequently, it is necessary to strengthen the capacity and capability of regional public officials in fiscal and public policy matters.
\end{abstract}

Penelitian ini bertujuan untuk menganalisis pengaruh desentralisasi fiskal terhadap pertumbuhan ekonomi provinsi di Indonesia. Analisis desentralisasi fiskal menggunakan indikator pendapatan, indikator belanja, dan indikator otonomi serta menggunakan variabel pengendali yang terdiri dari pertumbuhan populasi, rasio investasi domestik terhadap PDRB, dan tingkat inflasi daerah. Studi ini menggunakan data panel 33 provinsi di Indonesia periode 2008-2012 dengan metode Random Effect Model (REM). Hasil penelitian ini menunjukkan bahwa desentralisasi fiskal tidak terbukti signifikan meningkatkan pertumbuhan ekonomi provinsi. Atas dasar hal tersebut, diperlukan peninjauan kembali kebijakan fiskal daerah terkait perencanaan dan penganggaran, serta penetapan skala prioritas pembangunan daerah. Sebagai konsekuensi, perlu adanya upaya penguatan kapasitas dan kapabilitas aparatur daerah di bidang kebijakan fiskal dan kebijakan publik. 


\section{PENDAHULUAN}

\subsection{Latar Belakang}

Banyak negara telah mengimplementasikan desentralisasi fiskal diantaranya adalah Indonesia yang dimulai pada tahun 2001. Guna membuktikan dampak dari penerapan desentralisasi fiskal, banyak ekonom telah meneliti pengaruh desentralisasi fiskal bagi perekonomian. Indikator yang digunakan adalah pertumbuhan ekonomi yang merefleksikan tingkat kesejahteraan masyarakat. Hasil penelitian terbagi atas tiga kelompok sesuai argumentasi logis dan bukti empiris masing-masing. Zhang dan Zou (1998), Davoodi dan Zou (1998), Xie et al. (1998), dan Pose dan Ezcurra (2010) memperoleh fakta bahwa pelaksanaan desentralisasi fiskal berdampak negatif terhadap pertumbuhan ekonomi. Woller dan Phillips (1998) memiliki bukti bahwa desentralisasi fiskal tidak mempunyai kaitan dengan pertumbuhan ekonomi. Sementara, Akai dan Sakata (2002), Iimi (2005), Wibowo (2008), Samimi et al. (2010), dan Faridi (2011) menemukan hasil bahwa desentralisasi fiskal berkontribusi dalam peningkatan pertumbuhan ekonomi.

Undang Undang (UU) Nomor 22 Tahun 1999 tentang Pemerintah Daerah dan UU Nomor 25 Tahun 1999 tentang Perimbangan Keuangan antara Pemerintah Pusat dan Daerah menjadi dasar hukum pelaksanaan desentralisasi fiskal di Indonesia. Tujuan pelaksanaan desentralisasi fiskal adalah untuk memberikan pelayanan yang lebih optimal kepada masyarkat. Untuk mendukung pelaksanaan tugastugas pemerintahan di daerah, pemerintah pusat mengalokasikan dana perimbangan atau dana transfer kepada daerah.

Sepanjang tahun 2008-2012, jumlah dana perimbangan terus mengalami peningkatan. Hal ini dapat ditunjukkan pada Tabel 1.1., yang menujukkan bahwa rasio dana perimbangan terhadap jumlah belanja negara berada pada rentang 28 persen hingga 31 persen. Sementara untuk rasio untuk DBH terhadap Dana Perimbangan ada pada rentang 26,5 persen hingga 29,1 persen, rasio untuk DAK terhadap Dana Perimbangan ada pada rentang 6,3 persen hingga 8,6 persen, dan rasio untuk DAU terhadap Dana Perimbangan ada pada rentang 64,4 persen ke
66,5 persen. Sementara itu bagi pemerintah daerah, Dana Perimbangan menjadi penyumbang pendapatan daerah terbesar, sebagaimana dapat dilihat pada Tabel 1.2.

Dengan adanya pemberian kewenangan kepada daerah untuk menjalankan otonomi seluasluasnya dalam mengatur dan mengurus sendiri urusan pemerintahan termasuk kebijakan fiskal beserta pembiayaannya, maka kewenangan belanja pemerintah daerah menjadi bertambah besar. Berdasarkan data keuangan pemerintah konsolidasi dapat diketahui bahwa sepanjang tahun 2008, belanja pemerintah daerah (pemerintah provinsi dan pemerintah kabupaten/kota) berkontribusi sebesar 28,45 persen terhadap belanja pemerintah konsolidasi. Angka ini semakin meningkat pada tahun-tahun berikutnya sebagaimana terlihat pada Tabel 1.3.

Semakin besarnya kontribusi belanja pemerintah daerah diharapkan mampu memberikan dampak signifikan bagi perekonomian daerah melalui penyediaan kebutuhan dan preferensi masyarakat di masing-masing daerah. Untuk melihat pengaruh realisasi belanja pemerintah daerah, salah satu indikator yang dapat digunakan adalah pertumbuhan ekonomi. Dengan menggunakan ukuran Produk Domestik Bruto (PDB) riil per kapita, pertumbuhan ekonomi Indonesia mengalami peningkatan sejak kebijakan desentralisasi fiskal mulai diterapkan, seperti terlihat pada Tabel 1.4 .

Dengan peningkatan jumlah belanja sepanjang periode 2008-2012, terdapat daerah dengan pertumbuhan PDRB riil per kapita yang cenderung mengalami kenaikan dari tahun ke tahun seperti Provinsi Aceh dan Papua Barat. Namun di sisi lain, terdapat pula daerah yang mengalami kondisi sebaliknya seperti Provinsi Nusa Tenggara Barat. Sementara itu, beberapa daerah lain memiliki pertumbuhan yang berfluktuatif seperti Provinsi Riau, Kalimantan Timur, dan Papua. Kondisi ini mengindikasikan bahwa terdapat ketimpangan kinerja perekonomian antar daerah, yang mana hal ini merupakan output atas kebijakan fiskal tiap-tiap pemerintah daerah.

Tabel 1.1 Realisasi Belanja Negara, 2008 - 2012

\begin{tabular}{cccccc}
\hline Tahun & Belanja Negara & Dana Perimbangan & DBH & DAU & DAK \\
\hline 2008 & $985.730,7$ & $278.714,6$ & $78.420,1$ & $179.507,1$ & $20.787,3$ \\
2009 & $937.382,0$ & $287.251,4$ & $76.129,9$ & $186.414,1$ & $24.707,4$ \\
2010 & $1.042 .117,2$ & $316.711,2$ & $92.183,4$ & $203.571,4$ & $20.956,3$ \\
2011 & $1.294 .999,1$ & $347.246,2$ & $96.908,9$ & $225.533,7$ & $24.803,5$ \\
2012 & $1.491 .410,2$ & $411.293,1$ & $111.537,2$ & $273.814,4$ & $25.941,4$ \\
\hline
\end{tabular}

Sumber: Kementerian Keuangan, 2008 - 2012 
Tabel 1.2 Komposisi Pendapatan Pemerintah Daerah Di Indonesia, 2008 - 2012

\begin{tabular}{lcrrrr}
\hline \multicolumn{1}{c}{ Uraian } & $\mathbf{2 0 0 8}$ & $\mathbf{2 0 0 9}$ & $\mathbf{2 0 1 0}$ & $\mathbf{2 0 1 1}$ & $\mathbf{2 0 1 2}$ \\
\hline Pendapatan Pemda & Rp376 T & Rp393 T & Rp446 T & Rp547 & Rp646 T \\
Share Dana Perimbangan & $73,35 \%$ & $71,56 \%$ & $68,10 \%$ & $62,97 \%$ & $62,80 \%$ \\
Share PAD & $17,20 \%$ & $17,16 \%$ & $18,15 \%$ & $19,94 \%$ & $20,40 \%$ \\
\hline
\end{tabular}

Keterangan: Pemerintah daerah adalah Pemerintah Provinsi dan Pemerintah Kabupaten/Kota

Sumber: Kementerian Keuangan, 2008 - 2012 (diolah)

Tabel 1.3 Realisasi Belanja Pemerintah Konsolidasi, 2008- 2012

\begin{tabular}{lrrrrr}
\hline \multicolumn{1}{c}{ Tahun } & $\mathbf{2 0 0 8}$ & \multicolumn{1}{c}{$\mathbf{2 0 0 9}$} & \multicolumn{1}{c}{$\mathbf{2 0 1 0}$} & \multicolumn{1}{c}{$\mathbf{2 0 1 1}$} & \multicolumn{2}{c}{$\mathbf{2 0 1 2}$} \\
\hline Belanja Konsolidasi & $\mathrm{Rp} 1,248 \mathrm{~T}$ & $\mathrm{Rp} 1,024 \mathrm{~T}$ & $\mathrm{Rp} 1,119 \mathrm{~T}$ & $\mathrm{Rp} 1,389 \mathrm{~T}$ & $\mathrm{Rp} 1,605$ \\
Share Belanja Pempus & $71,55 \%$ & $61,38 \%$ & $62,31 \%$ & $63,59 \%$ & $62,95 \%$ \\
Share Belanja Pemda & $28,45 \%$ & $38,62 \%$ & $37,69 \%$ & $36,41 \%$ & $37,05 \%$ \\
\hline
\end{tabular}

Keterangan : Untuk belanja pemerintah pusat dan provinsi, nilai belanja adalah angka belanja netto (tanpa memperhitungkan belanja transfer).

Sumber : Kementerian Keuangan, 2008-2012 (diolah)

Tabel 1.4 Pertumbuhan PDRB Riil Per Kapita Provinsi di Indonesia, 2008 - 2012

\begin{tabular}{|c|c|c|c|c|c|c|}
\hline No & Provinsi & 2008 & 2009 & 2010 & 2011 & 2012 \\
\hline 1 & Aceh & -7.29 & -5.39 & -2.15 & 2.65 & 3.01 \\
\hline 2 & Sumatera Utara & 4.93 & 4.00 & 5.34 & 5.08 & 4.73 \\
\hline 3 & Sumatera Barat & 5.17 & 2.99 & 4.61 & 4.79 & 4.95 \\
\hline 4 & Riau & 1.93 & -0.87 & 0.72 & 2.27 & 0.85 \\
\hline 5 & Jambi & 4.30 & 3.63 & 4.81 & 6.49 & 5.45 \\
\hline 6 & Sumatera Selatan & 2.91 & 2.23 & 3.82 & 4.86 & 4.42 \\
\hline 7 & Bengkulu & 3.74 & 3.89 & 4.51 & 4.58 & 4.76 \\
\hline 8 & Lampung & 3.76 & 4.02 & 4.73 & 5.03 & 5.17 \\
\hline 9 & Kep Bangka Belitung & 1.29 & 0.38 & 2.91 & 4.14 & 3.40 \\
\hline 10 & Kepulauan Riau & 1.76 & -1.87 & 2.23 & 3.24 & 3.49 \\
\hline 11 & DKI Jakarta & 4.47 & 3.68 & 5.09 & 5.51 & 5.34 \\
\hline 12 & Jawa Barat & 3.98 & 2.32 & 4.28 & 4.79 & 4.60 \\
\hline 13 & Jawa Tengah & 4.90 & 4.98 & 5.53 & 5.12 & 5.46 \\
\hline 14 & D.I Yogyakarta & 3.65 & 3.46 & 3.94 & 3.89 & 4.06 \\
\hline 15 & Jawa Timur & 4.83 & 4.36 & 6.02 & 6.43 & 6.53 \\
\hline 16 & Banten & 2.74 & 1.81 & 3.30 & 3.89 & 3.74 \\
\hline 17 & Bali & 3.51 & 3.09 & 3.73 & 5.14 & 5.33 \\
\hline 18 & Nusa Tenggara Barat & 1.34 & 10.90 & 5.23 & -4.09 & -2.49 \\
\hline 19 & Nusa Tenggara Timur & 2.48 & 2.15 & 3.21 & 3.79 & 3.65 \\
\hline 20 & Kalimantan Barat & 4.19 & 3.94 & 4.58 & 4.15 & 4.04 \\
\hline 21 & Kalimantan Tengah & 4.04 & 3.78 & 4.71 & 4.22 & 4.18 \\
\hline 22 & Kalimantan Selatan & 4.13 & 3.27 & 3.59 & 4.07 & 3.74 \\
\hline 23 & Kalimantan Timur & 1.01 & -1.76 & 1.37 & 1.32 & 1.27 \\
\hline 24 & Sulawesi Utara & 9.15 & 6.63 & 5.87 & 6.09 & 6.58 \\
\hline 25 & Sulawesi Tengah & 5.47 & 5.71 & 6.73 & 7.22 & 7.38 \\
\hline 26 & Sulawesi Selatan & 6.23 & 5.14 & 7.01 & 6.34 & 7.17 \\
\hline 27 & Sulawesi Tenggara & 4.85 & 5.35 & 6.09 & 6.55 & 8.02 \\
\hline 28 & Gorontalo & 5.15 & 5.09 & 5.40 & 5.87 & 5.95 \\
\hline 29 & Sulawesi Barat & 8.96 & 3.15 & 9.11 & 8.20 & 6.92 \\
\hline 30 & Maluku & 1.23 & 2.46 & 3.65 & 4.13 & 5.85 \\
\hline 31 & Maluku Utara & 3.24 & 3.44 & 5.47 & 4.02 & 4.33 \\
\hline 32 & Papua Barat & 3.93 & 9.51 & 24.00 & 23.67 & 12.88 \\
\hline \multirow[t]{2}{*}{33} & Papua & -6.21 & 15.27 & -8.05 & -7.21 & -0.92 \\
\hline & Nasional & 3.87 & 3.36 & 4.45 & 5.22 & 9.99 \\
\hline
\end{tabular}

Sumber: Badan Pusat Statistik (BPS), 2008 - 2012 
Berdasarkan uraian di atas, dua hal yang menjadi pokok perhatian adalah: 1).Saat ini Indonesia sedang menjalankan kebijakan desentralisasi fiskal; 2).Kebijakan desentralisasi fiskal dan peningkatan belanja pemerintah daerah memberikan pengaruh yang berbeda-beda bagi perekonomian daerah. Atas dasar hal tersebut, maka peneliti tertarik untuk mengkaji lebih jauh bagaimana pengaruh desentralisasi fiskal terhadap pertumbuhan ekonomi provinsi di Indonesia.

\section{LANDASAN TEORI DAN PENGEMBANG- AN HIPOTESIS}

\subsection{Teori Pertumbuhan}

Kuznets (1966) mendefinisikan pertumbuhan ekonomi sebagai kenaikan jangka panjang kemampuan suatu negara untuk menyediakan semakin banyak jenis barang ekonomi kepada penduduknya yang tumbuh seiring dengan kemajuan teknologi dan penyesuaian kelembagaan dan ideologi yang diperlukannya. ${ }^{1}$ Sementara itu, mendefinisikan pertumbuhan ekonomi dengan proses kenaikan output per kapita dalam jangka panjang. ${ }^{2}$ Indikator yang dapat digunakan untuk mengukur pertumbuhan ekonomi adalah pendapatan per kapita. ${ }^{3}$ Indikator ini merefleksikan upaya dari suatu wilayah untuk meningkatkan PDRB pada suatu titik dimana tingkat pertumbuhan PDRB lebih besar dibandingkan tingkat pertumbuhan penduduk.

Model Pertumbuhan Solow (Solow Growth Model) menunjukkan bagaimana pengaruh pertumbuhan persediaan modal, pertumbuhan angkatan kerja, dan kemajuan teknologi berinteraksi dalam suatu perekonomian terhadap output total barang dan jasa suatu negara. 4 Akumulasi modal terjadi pada saat sebagian dari pendapatan ditabung dan diinvestasikan kembali dengan tujuan memperbesar output dan pendapatan di kemudian hari. Pertumbuhan penduduk dan pertumbuhan angkatan kerja dianggap sebagai faktor yang memacu pertumbuhan ekonomi. Jumlah tenaga kerja yang lebih besar berarti akan meningkatkan tenaga kerja produktif sementara pertumbuhan penduduk yang lebih besar akan meningkatkan ukuran pasar domestiknya. Namun model Solow juga memprediksikan bahwa negara-negara dengan pertumbuhan populasi yang lebih tinggi akan

1 M.L. Jhingan, Ekonomi Pembangunan dan Perencanaan (Jakarta: Raja Grafindo Persada 2012), hlm. 57.

2 Boediono, Teori Pertumbuhan Ekonomi (Yogyakarta: BPFE, 1999), hlm. 1.

3 Sadono Sukirno, Pengantar Teori Makroekonomi (Jakarta: Raja Grafindo Persada, 2002), hlm. 416.

4 N. Gregory Mankiw, Macroeconomics (New York: Worth Publisher, 2012), hlm. 205. memiliki tingkat PDB per kapita yang lebih rendah. Artinya semakin besar jumlah penduduk maka semakin kecil jumlah modal per pekerja dan berdampak pada rendahnya output per pekerja. Kemajuan teknologi menurut Solow merupakan variabel eksogen yang dapat meningkatkan kemampuan masyarakat untuk berproduksi sepanjang waktu.

\subsection{Desentralisasi Fiskal}

Desentralisasi sebagai proses transfer kekuasaan dalam membuat keputusan pada pemerintah daerah. ${ }^{5}$ Oates (2007) menyebutkan bahwa desentralisasi memberikan keunggulan informasi, kedekatan fisik, dan institusi bagi pemerintah daerah untuk mencapai efisiensi ekonomi dalam penyediaan pelayanan publik di daerah. Iimi (2005) menyatakan bahwa desentralisasi memiliki beberapa dimensi yaitu desentralisasi politik, desentralisasi administrasi, dan desentralisasi fiskal. Desentralisasi fiskal adalah cara setiap negara dalam mengatur sektor publik yang mencerminkan sejarah, geografi, keseimbangan politik, tujuan politik, dan karakteristik lain yang berbeda. ${ }^{6}$ Menurut Tiebout (1956) dan Klugman (1994), teori desentralisasi fiskal berangkat dari keunggulan informasi dan pemahaman yang lebih baik atas preferensi masyarakat sehingga pemerintah daerah lebih mampu menyediakan pelayanan dan barang publik sesuai dengan kebutuhan masyarakat. ${ }^{7}$ Desentralisasi fiskal adalah pendelegasian tanggung jawab serta pembagian kekuasaan dan kewenangan untuk pengambilan keputusan di bidang fiskal yang meliputi aspek penerimaan maupun aspek pengeluaran. ${ }^{8}$

Dalam membahas desentralisasi fiskal, umumnya terdapat dua variabel yang seringkali digunakan sebagai representasi desentralisasi fiskal yaitu desentralisasi penerimaan dan desentralisasi pengeluaran, sebagaimana diajukan oleh Zhang dan Zou (1998) dan Woller dan Phillips (1998). Namun, Akai dan Sakata (2002) menambahkannya dengan indikator otonomi dengan pertimbangan: 1) pengeluaran pemerintah daerah dapat bersumber dari block transfer yang berasal dari pemerintah pusat. Porsi pengeluaran pemerintah daerah yang

5 R.M. Bird and F. Vaillancourt, Fiscal Decentralization in Development Countries (London: Cambridge University Press, 1998), hlm. 4.

6 Ibid., hlm. 15.

7 Andres Rodrigues Pose and Roberto Ezcurra, Is Fiscal Decentralization Harmful for Economic Growth? Evidence from the OECD Countries, Spatial Economic Research Center, 2010, hlm. 6.

8 Abdul Halim, (2009). Problem Desentralisasi dan Perimbangan Keuangan Pemerintahan PusatDaerah (Yogyakarta: Sekolah Pasca Sarjana UGM, 2009), hlm. 45. 
besar tidak serta merta mengindikasikan kemandirian dikarenakan masih terkandung dana perimbangan yang merupakan perwujudan otorisasi dari level pemerintah yang lebih tinggi, 2) suatu daerah dapat dikatakan memiliki kemampuan fiskal secara otonom apabila memiliki sumber PAD yang cukup besar meskipun porsinya terhadap penerimaan dan pengeluaran pemerintah keseluruhan tidak besar.

Teori pertumbuhan menyatakan bahwa salah satu faktor yang mempengaruhi pertumbuhan ekonomi adalah akumulasi modal. Salah satu tujuan desentralisasi fiskal adalah untuk meningkatkan akumulasi modal yang ada di daerah dengan memberikan kewenangan yang luas kepada daerah dalam perencanaan dan pemanfaatan anggaran. Akumulasi modal di daerah diharapkan dapat memberikan pengaruh positif bagi perekonomian daerah.

\subsection{Desentralisasi Fiskal dan Pertumbuhan Ekonomi}

Oates (1993) menegaskan bahwa tingkat kemajuan ekonomi merupakan outcome dari kesesuaian preferensi antara masyarakat dan pemerintah daerah. Secara teori, desentralisasi fiskal diperkirakan akan memberikan peningkatan ekonomi mengingat pemerintah daerah mempunyai kedekatan dengan masyarakat dan mempunyai keunggulan informasi sehingga dapat memberikan pelayanan publik yang benar-benar dibutuhkan di daerahnya. ${ }^{9}$ Keterkaitan antara desentralisasi fiskal dan pertumbuhan ekonomi didasarkan pada dua asumsi bahwa: 1) bahwa desentralisasi akan meningkatkan efisiensi ekonomi karena pemerintah daerah diposisikan lebih baik dari pemerintah pusat dalam memberikan pelayanan publik sebagai hasil keuntungan informasi; dan 2) kebutuhan penduduk dan persaingan antarpemerintah daerah untuk pelayanan publik akan menjamin sesuai kebutuhan masyarakat lokal dan pemerintah daerah. ${ }^{10}$ Prud'homme (1995) meyakini bahwa desentralisasi fiskal dapat berdampak positif terhadap perkembangan ekonomi daerah di masa datang. Secara eksplisit dinyatakan bahwa pengeluaran publik terutama penyediaan infrastruktur bagi masyarakat akan lebih efektif dilakukan oleh pemerintah daerah karena lebih mengetahui apa yang menjadi keinginan dan kebutuhan masyarakat lokal.

9 P. Wibowo, (2008). “Mencermati Dampak Desentralisasi Fiscal Terhadap Pertumbuhan Ekonomi Daerah", Jurnal Keuangan Publik, Vol. 5 No. 1, hlm 56.

${ }^{10}$ H. Davoodi \& H. Zou, (1998). "Fiscal Decentralization and Economic Growth: A CrossCountry Study", Journal of Urban Economics, hlm. $244-257$.

\subsection{Model Penelitian}

Berdasarkan teori pertumbuhan dan hasil empiris yang ada pada studi-studi sebelumnya, maka penelitian ini akan memasukkan tiga variabel yang akan dijadikan sebagai variabel pengendali, yaitu pertumbuhan penduduk, investasi, dan inflasi. Oleh karena itu, model ekonometrik yang dikembangkan dalam penelitian ini adalah sebagai berikut:

$$
\begin{aligned}
\Delta Y_{i t}= & \beta_{0}+\beta_{1} \text { Poprates }_{i t}+\beta_{2} \text { Investasi }_{i t}+ \\
& \beta_{3} \text { Inflasi }_{i t}+\propto_{1} R_{i t}+\propto_{2} E_{i t}+\propto_{3} A I_{i t}+\varepsilon_{i t}
\end{aligned}
$$

\begin{tabular}{|c|c|c|}
\hline$\Delta \mathrm{Y}$ & : & pertumbuhan PDRB riil per kapita; \\
\hline Poprates & : & pertumbuhan populasi; \\
\hline Inflasi & : & $\begin{array}{l}\text { tingkat kenaikan harga-haga secara } \\
\text { umum; }\end{array}$ \\
\hline Investasi & : & $\begin{array}{l}\text { rasio investasi domestik terhadap } \\
\text { PDRB; }\end{array}$ \\
\hline RI & : & indikator pendapatan; \\
\hline I & : & indikator belanja; \\
\hline & : & indikator otonomi; \\
\hline & : & $\begin{array}{l}\text { random error yang diasumsikan } \\
\text { bersifat homoskedastic, terdistribusi } \\
\text { secara normal, dan independen; }\end{array}$ \\
\hline$\beta_{0}$ & : & $\begin{array}{l}\text { intercept yang menunjukkan } \\
\text { endowment pertumbuhan ekonomi; }\end{array}$ \\
\hline$\beta_{1,2,3}$ & : & $\begin{array}{l}\text { estimasi parameter nilai variabel } \\
\text { pengendali; }\end{array}$ \\
\hline$\alpha_{1,2,3}$ & : & $\begin{array}{l}\text { estimasi parameter nilai indikator } \\
\text { desentralisasi fiskal; }\end{array}$ \\
\hline & : & provinsi; dan \\
\hline & & periode waktu. \\
\hline
\end{tabular}

Dimana:

\subsection{Hipotesis}

Hipotesis penelitian diidentifikasikan sebagai dasar untuk menganalisis pertanyaan penelitian. Hipotesis dirumuskan sebagai berikut.

Ho: $\quad \alpha_{1,2,3} \leq 0 \quad$ Desentralisasi fiskal tidi berpengaruh positif dan signifik: terhadap PDRB riil per kapita.

Ha: $\quad \alpha_{1,2,3} \geq 0 \quad$ Desentralisasi fiskal berpengarı positif dan signifikan terhadap PDF riil per kapita.

\section{METODOLOGI PENELITIAN}

\subsection{Data}

Data yang digunakan dalam penelitian ini berupa data panel yang mana merupakan gabungan antara data time series dan data cross section. Data time series menggunakan data dari tahun 2008-2012, dan data cross section menggunakan 33 provinsi di Indonesia. Data diperoleh dari Badan Pusat Statistik dan Kementerian Keuangan. Penggunaan data sampai dengan tahun 2012 lebih dikarenakan keterbatasan data PDRB tahun setelahnya. 


\subsection{Metode Analisis Data}

Metode analisis data yang digunakan yaitu metode regresi data panel. Untuk mengestimasi parameter model dengan data panel, terdapat tiga metode yang digunakan yaitu Common Effect Model, Fixed Effect Model, dan Random Effect Model. ${ }^{11}$ Tiga uji untuk memilih teknik estimasi data panel adalah sebagai berikut yaitu Uji Statistik F, Uji Hausman, dan Uji Lagrange Multiplier (LM). ${ }^{12}$

Instrumen penelitian terdiri atas pengujian asumsi klasik dan pengujian hipotesis. Pengujian asumsi klasik meliputi uji Autokorelasi, uji Heteroskedastisitas, uji Multikolinieritas, dan uji Normalitas, namun tidak semua uji asumsi klasik harus dilakukan pada data panel. Sementara pengujian hipotesis meliputi koefisien determinasi, uji F, dan uji t.

Sebagaimana studi yang telah dilakukan oleh peneliti sebelumnya, analisis pengaruh desentralisasi fiskal terhadap pertumbuhan ekonomi dilakukan dengan memasukkan beberapa variabel pengendali yang menjadi determinan pertumbuhan ekonomi. Hal ini dimaksudkan agar pengaruh desentralisasi fiskal tersebut dapat juga dilihat secara bersama-sama dengan variabel lain dalam peranannya terhadap pertumbuhan ekonomi. Variabel pengendali yang digunakan dalam penelitian ini adalah sebagai berikut.

3.2.1 Pertumbuhan penduduk, adalah perubahan jumlah penduduk tahun berjalan dibanding tahun sebelumnya dengan menggunakan satuan persentase. Variabel ini digunakan pula dalam penelitian Woller dan Phillips (1998), Akai dan Sakata (2002), Iimi (2004), dan Wibowo (2008).

3.2.2 Investasi, adalah rasio investasi domestik terhadap PDRB dengan menggunakan satuan persentase. Variabel ini digunakan dalam penelitian Zhang dan Zou (1998), Woller dan Phillips (1998), Xie et al. (1999), dan Wibowo (2008).

3.2.3 Inflasi, adalah kenaikan harga-harga secara umum dan terus menerus di tiap-tiap provinsi dengan menggunakan satuan persentase. Variabel ini digunakan dalam penelitian Zhang dan Zou (1998), Woller dan Phillips (1998), Xie et al. (1999), dan Faridi (2011).

Sementara variabel indikator desentralisasi fiskal terdiri atas indikator pendapatan, indikator belanja, dan indikator otonomi. Indikator ini digunakan dalam penelitian Zhang dan Zou (1998),

11 A Widarjono, (2007). Ekonometrika: Teori dan Aplikasi untuk Ekonomi dan Bisnis. Yogyakarta: Ekonisia, hlm 251.

12

Ibid., hlm. 258.
Woller dan Phillips (1998), Akai dan Sakata (2002), dan Wibowo (2008). Definisi dari masing-masing indikator desentralisasi fiskal tersebut adalah sebagai berikut.

a. Indikator pendapatan (RI).

Rasio RI merupakan share jumlah pendapatan seluruh pemerintah daerah di suatu provinsi terhadap pendapatan pemerintah konsolidasi (pemerintah pusat, pemerintah provinsi, dan pemerintah kabupaten/kota). Rasio ini serupa dengan indikator yang diajukan oleh Woller dan Phillips (1998).

b. Indikator belanja (EI).

Rasio EI menghitung share jumlah belanja seluruh pemerintah daerah di suatu provinsi terhadap belanja pemerintah konsolidasi. EI merupakan modifikasi dari indikator yang diusulkan oleh Akai dan Sakata (2002).

c. Indikator otonomi (AI).

Indikator ini digunakan karena suatu daerah dapat memperoleh dana perimbangan yang kecil, akan tetapi pendelegasian fiskal disebut tinggi apabila PAD daerah tersebut mampu mendanai pengeluaran dalam porsi yang lebih besar. Rasio AI merupakan share total PAD terhadap jumlah pendapatan seluruh pemerintah daerah dalam satu provinsi dengan memperhitungkan dana perimbangan. AI merupakan modifikasi dari indikator yang diusulkan oleh Akai dan Sakata (2002).

\section{HASIL PENELITIAN}

\subsection{Uji Akurasi Instrumen dan Hasil Estimasi}

Guna menentukan model yang paling tepat untuk mengestimasi data panel, terlebih dahulu dilakukan pengujian model. Pada uji Statistik F, diperoleh hasil seperti pada Tabel 4.1.

Tabel 4.1 Hasil Uji Statistik F

\begin{tabular}{lccc}
\hline Effects Test & Statistic & d.f. & Prob. \\
\hline Cross-section F & 4.706422 & $(32,126)$ & 0.0000 \\
\hline $\begin{array}{l}\text { Cross-section Chi- } \\
\text { square }\end{array}$ & 129.741222 & 32 & 0.0000 \\
\hline
\end{tabular}

Sumber: Lampiran II

Hasil uji memperlihatkan bahwa nilai probabilitas lebih kecil dibandingkan level kesalahan 5 persen. Dengan demikian, Fixed Effect Model merupakan metode yang lebih baik digunakan untuk melakukan analisis data panel. Sementara pada uji Hausman diperoleh hasil sebagaimana pada Tabel 4.2 . 
Tabel 4.2 Hasil Uji Hausman

\begin{tabular}{lccc}
\hline Test Summary & Chi-Sq. Statistic & Chi-Sq. d.f. & Prob. \\
$\begin{array}{l}\text { Cross-section } \\
\text { random }\end{array}$ & 7.062177 & 6 & 0.3151 \\
\hline
\end{tabular}

Sumber: Lampiran III

Hasil uji memperlihatkan bahwa nilai probabilitas lebih besar dibandingkan level kesalahan 5 persen. Dengan demikian, Random Effect Model merupakan metode yang paling tepat untuk menganalisis data panel dalam penelitian ini. Untuk model dengan menggunakan data panel dan metode Random Effect Model, tidak perlu dilakukan uji asumsi klasik dikarenakan: 1).Masalah multikolinearitas yang mengakibatkan tidak tepatnya penaksiran dapat diatasi dengan menggabungkan data cross section dan time series; ${ }^{13}$ 2).Tidak perlu dilakukan uji heteroskedastisitas dikarenakan pada data panel dengan metode Random Effect Model sudah terkandung generalized least square (GLS) dalam estimasinya. ${ }^{14}$ Hasil estimasi data panel adalah sebagaimana Tabel 4.3.

Tabel 4.3 Hasil Estimasi

\begin{tabular}{lccc}
\hline \multicolumn{1}{c}{ Variable } & Coefficient & t-Statistic & Prob. \\
\hline C & 5.792767 & 5.610022 & 0.0000 \\
Poprates & -0.143563 & -2.171945 & 0.0314 \\
Investasi & 0.357353 & 1.940796 & 0.0541 \\
Inflasi & -0.157816 & -2.458220 & 0.0150 \\
RI & 273.8013 & 1.147628 & 0.2529 \\
EI & -275.7708 & -1.351879 & 0.1783 \\
AI & -1.962564 & -0.449421 & 0.6537 \\
\hline R-squared & 0.098037 & & \\
F-statistic & 2.862251 & & \\
Prob (F- & & & \\
statistic) & 0.011279 & & \\
\hline
\end{tabular}

Sumber: Lampiran IV

Nilai estimasi $\mathrm{R}^{2}$ menunjukkan angka 0,098 yang berarti variabel pengendali memberikan kontribusi sebesar 9,8 persen terhadap pertumbuhan ekonomi provinsi. Hasil uji $\mathrm{F}$ menunjukkan probabilitas lebih kecil dibandingkan level kesalahan 5 persen. Artinya keseluruhan variabel secara bersama-sama berpengaruh signifikan terhadap pertumbuhan ekonomi provinsi. Sementara hasil uji $t$ memperlihatkan bahwa tidak satupun indikator desentralisasi fiskal yang terbukti memberikan kontribusi bagi pertumbuhan ekonomi provinsi.

13 Maryatmo Insukindro \& Aliman, (2001). Modul Ekonometrika Dasar dan Penyusunan Indikator Unggulan Ekonomi, hlm. 71.

14 Akbar Suwardi, (2011). STATA: Tahapan dan Perintah (Syntax) Data Panel. Jakarta: Departemen Ilmu Ekonomi FEUI, hlm. 3.

\subsection{Pembahasan}

Berdasarkan hasil estimasi, variabel pengendali yang secara empiris menjadi determinan pertumbuhan ekonomi terbukti dalam penelitian ini. Semua koefisien menunjukkan arah yang sesuai dengan teori. Pertumbuhan populasi memiliki arah hubungan negatif dengan pertumbuhan ekonomi, seperti pendapat yang dikemukakan oleh teori Solow bahwa semakin besar jumlah penduduk akan mengakibatkan jumlah modal per pekerja yang semakin kecil dan berdampak pada rendahnya output per pekerja. Tingkat investasi berhubungan positif terhadap kinerja ekonomi. Inflasi secara signifikan mengurangi laju perekonomian sejalan dengan teori kuantitas uang yang menyatakan bahwa pertumbuhan output akan menurun pada saat terjadi inflasi.

Selanjutnya, hasil estimasi memperlihatkan bahwa dari tiga jenis indikator variabel desentralisasi fiskal, tidak ada satu pun yang terbukti signifikan meningkatkan pertumbuhan ekonomi. Artinya bahwa hasil estimasi tidak sesuai dengan hipotesis yang diajukan. Dalam risetnya, Woller dan Phillips (1998) juga menemukan kesimpulan yang sama.

Indikator pendapatan yang diwakili oleh variabel RI memiliki arah koefisien positif. Artinya adalah desentralisasi pendapatan yang diterima oleh pemerintah daerah berhasil meningkatkan pertumbuhan ekonomi daerah. Semakin besar pendapatan yang diterima oleh pemerintah daerah akan semakin meningkatkan pertumbuhan ekonomi di daerah tersebut. Indikator pendapatan dengan arah koefisien positif ini dapat ditemukan pula pada hasil penelitian yang dilakukan oleh Akai dan Sakata (2002), Wibowo (2008), Samimi (2010), dan Faridi (2011), namun berkebalikan dengan hasil temuan Woller dan Phillips (1998). Namun demikian, kesimpulan tersebut dapat diabaikan dikarenakan tingkat signifikansi yang tidak dapat dicapai pada berbagai tingkatan.

Indikator belanja yang diwakili oleh variabel EI memiliki arah koefisien negatif, artinya adalah desentralisasi belanja yang diterima oleh pemerintah daerah cenderung menghambat perekonomian daerah. Hasil penelitian serupa dapat ditemukan pada penelitian Zhang dan Zou (1998), Davoodi dan Zou (1998), dan Pose dan Ezcurra (2010), namun bertolak belakang dengan hasil penelitian Akai dan Sakata (2002), Iimi (2005), Wibowo (2008), dan Faridi (2011) yang menyatakan bahwa belanja pemerintah daerah memberikan kontribusi positif bagi pertumbuhan ekonomi. Hal ini dimungkinkan terjadi apabila kebijakan belanja yang dilakukan oleh pemerintah daerah belum mampu memenuhi prioritas yang yang dibutuhkan oleh masyarakat dan tidak berorientasi pada upaya perbaikan iklim perekonomian. Hal ini dapat pula diartikan dengan kekurangmampuan aparatur pemerintah daerah dalam menyusun perencanan dan penganggaran 
yang baik. Program dan kegiatan tidak ditujukan untuk menerapkan program-program yang merangsang investasi, akibatnya pertumbuhan ekonomi yang diharapkan tidak terjadi. Misalnya, realisasi belanja daerah yang lebih didominasi oleh belanja pegawai dan belanja barang. Namun demikian, kesimpulan ini dapat diabaikan dikarenakan signifikansi yang tidak dapat dicapai pada berbagai tingkatan.

Sementara indikator otonomi memiliki arah koefisien yang negatif. Hasil ini juga diperoleh Akai dan Sakata (2002) dan Wibowo (2008) dalam risetnya. Kondisi ini mengindikasikan bahwa kebijakan perolehan penerimaan daerah (pajak daerah dan retribusi daerah) sepanjang periode penelitian cenderung membebani perekonomian daerah. Hal ini dimungkinkan terjadi karena aparatur daerah kurang memahami best practices pengelolaan anggaran, kurang berpengalaman dalam mengelola anggaran, ataupun memiliki persiapan yang kurang matang dalam menghadapi era otonomi. ${ }^{15}$ UU No. 28 tahun 2009 tentang Pajak Daerah dan Retribusi Daerah telah memberikan kewenangan kepada pemerintah daerah untuk mengenakan pungutan atas pajak daerah dan retribusi daerah. UU tersebut mengatur batas tertinggi tarif pajak daerah yang dapat dikenakan. Dengan keleluasaan tersebut, disinyalir pemerintah daerah berusaha untuk memaksimalkan pendapatannya dengan menetapkan tarif pajak dengan batas tertinggi tanpa melalui kajian-kajian yang memadai terkait dampak yang timbul bagi masyarakat. Namun demikian, kesimpulan ini dapat juga diabaikan dikarenakan signifikansi yang tidak dapat dicapai pada berbagai tingkatan.

Davoodi dan Zou (1998) mengemukakan bahwa terdapat beberapa faktor yang menyebabkan desentralisasi fiskal menjadi kurang menguntungkan bagi pertumbuhan ekonomi daerah. Faktor-faktor tersebut antara lain:

4.2.1 Komposisi pengeluaran pemerintah daerah yang kurang tepat. Hal ini dimungkinkan terjadi bila belum ada persepsi dan pemahaman yang sama dalam mengkategorikan jenis belanja, rencana kerja, dan kerangka pembangunan. Pengeluaran yang berlebihan untuk alokasi yang kurang tepat berdampak pada pertumbuhan ekonomi yang rendah;

4.2.2 Penetapan kewenangan perolehan pendapatan yang kurang tepat pada pemerintah daerah, sebagai contoh: pemerintah daerah dapat mengenakan pajak yang pada hakekatnya menjadi hak/ kewenangan pemerintah pusat;

15 P Wibowo, (2008). Mencermati Dampak Desentralisasi Fiscal Terhadap Pertumbuhan Ekonomi Daerah. Jurnal Keuangan Publik, Vol. 5 No. 1, hlm 73.
4.2.3 Masih adanya pertentangan antara pemerintah daerah dengan pemerintah pusat terkait dengan penentuan perolehan pendapatan dan kebijakan belanja;

4.2.4 Pemerintah daerah belum mampu memenuhi preferensi dan kebutuhan masyarakat. Hal ini terjadi karena aparatur daerah tidak memiliki kapabilitas yang memadai, dan masyarakat tidak diberikan hak untuk melakukan evaluasi kinerja.

\section{KESIMPULAN DAN SARAN}

\subsection{Kesimpulan}

Simpulan dari penelitian ini adalah bahwa desentralisasi fiskal tidak terbukti signifikan berhasil memberikan kontribusi bagi pertumbuhan ekonomi daerah sebagaimana yang diharapkan. Hasil penelitian ini melengkapi penelitian yang telah dilakukan oleh Woller dan Phillips (1998).

\subsection{Saran}

Indikator desentralisasi fiskal yang lebih tepat perlu dikembangkan terutama untuk menganalisis dampak otonomi fiskal. Proses institusional dan keputusan politik yang mempengaruhi penentuan pendapatan dan alokasi pengeluaran publik perlu diakomodir dalam model. Dengan demikian, pada penelitian selanjutnya perlu untuk mengusulkan suatu model yang lebih komprehensif, dengan indikator desentralisasi fiskal yang lebih luas serta cakupan waktu yang lebih panjang untuk mengetahui dampak desentralisasi fiskal terhadap pembangunan.

\section{IMPLIKASI DAN KETERBATASAN 6.1. Implikasi}

Implikasi kebijakan yang dapat dihasilkan dari penelitian ini adalah sebagai berikut.

6.1.1 Pemerintah daerah perlu meningkatkan kapasitas dan kapabilitas aparatur pemerintah daerah dalam bidang pendapatan daerah, terkait dengan dasar pemungutan pajak daerah, retribusi daerah dan dampaknya bagi perekonomian.

6.1.2 Upaya peningkatan kapasitas dan kapabilitas juga perlu dilakukan pada aparatur pemerintah daerah dalam bidang belanja daerah terkait penyusunan perencanaan dan penganggaran sesuai dengan prioritas pembangunan, preferensi dan kebutuhan masyarakat.

\subsection{Keterbatasan}

Indikator desentralisasi fiskal yang disusun dalam penelitian ini cenderung menggunakan ukuran-ukuran akuntansi, yaitu pendapatan dan belanja. Penelitian ini hanya berupaya menunjukkan bukti empiris yang menyatakan adanya hubungan positif antara pendelegasian fiskal yang semakin besar dengan tingkat kesejahteraan penduduk di daerah. Sementara dalam kenyataannya, konsep 
desentralisasi fiskal merupakan hasil dari keputusan dan kebijakan pemerintah dengan mempertimbangkan berbagai variabel, seperti politik dan faktor kelembagaan. Dengan demikian, model yang mengakomodir hubungan timbal balik antar variabel- variabel dimaksud, dibutuhkan untuk keakuratan analisis atas dampak desentralisasi fiskal terhadap kemajuan ekonomi.

\section{DAFTAR PUSTAKA (REFERENCES)}

Akai, Nobuo \& Sakata, Masayo. (2002). "Fiscal Decentralization Contributes to Economic Growth: Evidence from State Level Cross Section Data for the United States", Journal of Urban Economics, Vol. 52, 93 - 108, 22 Maret 2002.

BPS.Statistik Pusat Indonesia. Jakarta.

Bird, R.M. \& Vaillancourt, F. (1998). Fiscal Decentralization in Development Countries. Cambridge University Press. London.

Davoodi, H. \& Zou, H. (1998). "Fiscal Decentralization and Economic Growth: A Cross-Country Study”, Journal Of Urban Economics, 43, hlm. 244 - 257. Article No. UE972042.

Faridi, M.Z. (2011). “Contribution of Fiscal Decentralization to Economic Growth: Evidence from Pakistan", Pakistan Journal of Social Science, Vol. 31, No. 1, 1-13.

Halim, Abdul. (2009). Problem Desentralisasi dan Perimbangan Keuangan Pemerintahan PusatDaerah. Sekolah Pascasarjana UGM. Yogyakarta.

Iimi, Atsushi. (2005). "Decentralization and Economic Growth Revisited: An Empirical Note”, Jurnal of Urban Economics, 57, hlm. 449 - 461.

Insukindro, Maryatmo, dan Aliman. (2001). "Modul Ekonometrika Dasar dan Penyusunan Indikator Unggulan Ekonomi", Disampaikan pada Workshop Ekonometrika dalam Rangka Penjajakan Leading Export, Makassar.

Jhingan, M.L. (2012). Ekonomi Pembangunan dan Perencanaan. Jakarta: Raja Grafindo Persada.

Kementerian Keuangan. Data Keuangan Daerah. Direktorat Jenderal Perimbangan Keuangan. http://www.djpk.depkeu.go.id.

Kementerian Keuangan. Laporan Keuangan Pemerintah Pusat. Direktorat Jenderal Perbendaharaan. http://www.perbendaharaan.go.id.

Mankiw, N. Gregory. (2012). Macroeconomi. United States of America: Worth Publisher.

Oates, Wallace E. (2007). “On The Theory and Practice of Fiscal Decentralization", Centro Di Recerca Interdipartementale Di Economia Della Institution, Working Paper No. 1/2007.
Pose, Andres Rodrigues \& Ezcurra, Roberto. (2010). "Is Fiscal Decentralization Harmful For Economic Growth? Evidence from the OECD Countries", Spatial Economic Research Center.

Prud'homme, Remy. (1995). “On the Danger of Decentralization", The World Bank, Policy Research Working Paper, 1252. Washington DC.

Samimi, A.J., Petanlar, S.K., Haddad, G.K., and Alizadeh, M. (2010). "Fiscal Decentralization and Economic Growth: Non Linear Model for Provinces of Iran", Iranian Economic Review, Volume 15, No. 26.

Sukirno, Sadono. (2002). Pengantar Teori Makroekonomi: Edisi Kedua. PT Raja Grafindo Persada. Jakarta

Suwardi, Akbar. (2011). STATA: Tahapan dan Perintah (Syntax) Data Panel. Departemen Ilmu Ekonomi FEUI. Jakarta.

Undang Undang Nomor 32 Tahun 2004 tentang Pemerintahan Daerah.

Undang Undang Nomor 33 Tahun 2004 tentang Perimbangan Keuangan Antara Pemerintah Pusat dan Pemerintahan Daerah.

Undang Undang Nomor 28 Tahun 2009 tentang Pajak Daerah dan Retribusi Daerah.

Wibowo, P. (2008). "Mencermati Dampak Desentralisasi Fiscal Terhadap Pertumbuhan Ekonomi Daerah", Jurnal Keuangan Publik, Vol. 5 No. 1.

Widarjono, A. (2007). Ekonometrika: Teori dan Aplikasi untuk Ekonomi dan Bisnis. Ekonisia. Yogyakarta.

Woller, M. Gary and Phillips, Kerk. (1998). "Fiscal Decentralization and LDC Economic Growth: An Empirical Investigation", The Journal of Development Studies, Vol. 34, No. 4.

Xie, D., Zou, H. and Davoodi, H. (1999). "Fiscal Decentralization and Economic Growth in the United States", Journal of Urban Economics 45.

Zhang, T. and Zou, H. (1998). "Fiscal Decentralization, Public Spending, and Economic Growth in China", Journal of Public Economics, LXVII, hlm. 221-240. 
LAMPIRAN I

Data Penelitian

\begin{tabular}{|c|c|c|c|c|c|c|c|c|c|}
\hline NO & PROV. & THN & $\mathbf{Y}$ & POP & INV & INF & RI & EI & AI \\
\hline \multirow[t]{5}{*}{1} & \multirow[t]{5}{*}{ Aceh } & 2008 & -7.29 & 1.66 & 0.00 & 10.27 & 0.011969 & 0.012301 & 0.044401 \\
\hline & & 2009 & -5.39 & 1.62 & 0.11 & 3.50 & 0.012567 & 0.017011 & 0.073655 \\
\hline & & 2010 & -2.15 & 3.00 & 0.05 & 4.64 & 0.012111 & 0.015881 & 0.066737 \\
\hline & & 2011 & 2.65 & 4.03 & 0.30 & 3.32 & 0.011511 & 0.014054 & 0.063873 \\
\hline & & 2012 & 3.01 & 0.85 & 0.06 & 0.07 & 0.011557 & 0.013218 & 0.069327 \\
\hline \multirow[t]{5}{*}{2} & \multirow{5}{*}{$\begin{array}{l}\text { Sumatera } \\
\text { Utara }\end{array}$} & 2008 & 4.93 & 1.62 & 0.18 & 10.63 & 0.013066 & 0.013238 & 0.122927 \\
\hline & & 2009 & 4.00 & 1.58 & 0.87 & 2.69 & 0.015257 & 0.018292 & 0.156373 \\
\hline & & 2010 & 5.34 & -2.01 & 0.24 & 7.65 & 0.014744 & 0.018237 & 0.178783 \\
\hline & & 2011 & 5.08 & 2.39 & 0.39 & 3.54 & 0.014975 & 0.018141 & 0.209389 \\
\hline & & 2012 & 4.73 & -0.28 & 0.73 & 1.97 & 0.016129 & 0.019503 & 0.201057 \\
\hline \multirow[t]{5}{*}{3} & \multirow{5}{*}{$\begin{array}{l}\text { Sumatera } \\
\text { Barat }\end{array}$} & 2008 & 5.17 & 1.39 & 0.00 & 12.68 & 0.007368 & 0.007515 & 0.078963 \\
\hline & & 2009 & 2.99 & 1.36 & 0.60 & 2.05 & 0.008507 & 0.010275 & 0.120845 \\
\hline & & 2010 & 4.61 & 0.39 & 0.08 & 7.84 & 0.007695 & 0.010036 & 0.138824 \\
\hline & & 2011 & 4.79 & 4.56 & 1.04 & 5.37 & 0.007498 & 0.008926 & 0.147168 \\
\hline & & 2012 & 4.95 & -1.61 & 0.80 & 1.34 & 0.007549 & 0.009134 & 0.135590 \\
\hline \multirow[t]{5}{*}{4} & \multirow[t]{5}{*}{ Riau } & 2008 & 1.93 & 2.33 & 0.71 & 9.02 & 0.013361 & 0.013260 & 0.083872 \\
\hline & & 2009 & -0.87 & 2.26 & 1.14 & 1.94 & 0.011255 & 0.016668 & 0.171839 \\
\hline & & 2010 & 0.72 & 4.37 & 0.30 & 7.00 & 0.012292 & 0.014365 & 0.147890 \\
\hline & & 2011 & 2.27 & 1.00 & 1.80 & 5.09 & 0.013315 & 0.014099 & 0.142979 \\
\hline & & 2012 & 0.85 & 6.38 & 1.16 & 1.77 & 0.013640 & 0.014846 & 0.149119 \\
\hline \multirow[t]{5}{*}{5} & \multirow[t]{5}{*}{ Jambi } & 2008 & 4.30 & 1.68 & 3.17 & 11.57 & 0.004801 & 0.005320 & 0.096084 \\
\hline & & 2009 & 3.63 & 1.65 & 0.48 & 2.49 & 0.005383 & 0.006879 & 0.117897 \\
\hline & & 2010 & 4.81 & 9.11 & 0.41 & 10.52 & 0.005912 & 0.006890 & 0.116875 \\
\hline & & 2011 & 6.49 & 1.02 & 3.37 & 2.76 & 0.005482 & 0.006216 & 0.146655 \\
\hline & & 2012 & 5.45 & 4.19 & 1.99 & 2.94 & 0.005738 & 0.006606 & 0.127959 \\
\hline \multirow[t]{5}{*}{6} & \multirow{5}{*}{$\begin{array}{l}\text { Sumatera } \\
\text { Selatan }\end{array}$} & 2008 & 2.91 & 1.45 & 0.28 & 11.15 & 0.009195 & 0.009877 & 0.091533 \\
\hline & & 2009 & 2.23 & 1.42 & 0.42 & 1.85 & 0.009993 & 0.011827 & 0.126397 \\
\hline & & 2010 & 3.82 & 3.15 & 1.10 & 6.02 & 0.010731 & 0.012311 & 0.128879 \\
\hline & & 2011 & 4.86 & 2.69 & 0.59 & 3.78 & 0.010938 & 0.012807 & 0.145540 \\
\hline & & 2012 & 4.42 & 1.01 & 1.42 & 1.04 & 0.011506 & 0.013209 & 0.142994 \\
\hline \multirow[t]{5}{*}{7} & \multirow[t]{5}{*}{ Bengkulu } & 2008 & 3.74 & 1.56 & 0.00 & 13.44 & 0.003362 & 0.003746 & 0.063316 \\
\hline & & 2009 & 3.89 & 1.52 & 0.00 & 2.88 & 0.003629 & 0.004415 & 0.092495 \\
\hline & & 2010 & 4.51 & 2.92 & 0.05 & 9.08 & 0.003494 & 0.004343 & 0.092855 \\
\hline & & 2011 & 4.58 & 5.53 & 0.00 & 3.96 & 0.003351 & 0.004006 & 0.098335 \\
\hline & & 2012 & 4.76 & -2.07 & 0.22 & 1.28 & 0.003367 & 0.003946 & 0.100477 \\
\hline \multirow[t]{5}{*}{8} & \multirow[t]{5}{*}{ Lampung } & 2008 & 3.76 & 1.39 & 1.00 & 14.82 & 0.006101 & 0.006223 & 0.107601 \\
\hline & & 2009 & 4.02 & 1.36 & 0.62 & 4.18 & 0.007005 & 0.008004 & 0.125051 \\
\hline & & 2010 & 4.73 & 1.55 & 0.25 & 9.95 & 0.007264 & 0.008693 & 0.150657 \\
\hline & & 2011 & 5.03 & 3.38 & 0.64 & 4.24 & 0.007604 & 0.009450 & 0.141744 \\
\hline & & 2012 & 5.17 & -0.77 & 0.21 & 1.67 & 0.008012 & 0.009665 & 0.151706 \\
\hline \multirow[t]{5}{*}{9} & \multirow[t]{5}{*}{ Babel } & 2008 & 1.29 & 1.43 & 0.01 & 18.40 & 0.002749 & 0.002667 & 0.078953 \\
\hline & & 2009 & 0.38 & 1.39 & 1.08 & 2.17 & 0.002861 & 0.003637 & 0.130952 \\
\hline & & 2010 & 2.91 & 7.48 & 0.00 & 9.36 & 0.002451 & 0.003321 & 0.156081 \\
\hline & & 2011 & 4.14 & -0.60 & 1.69 & 5.00 & 0.002751 & 0.003016 & 0.150752 \\
\hline & & 2012 & 3.40 & 7.15 & 1.55 & 2.83 & 0.002743 & 0.003140 & 0.140069 \\
\hline \multirow[t]{5}{*}{10} & Kepulauan & 2008 & 1.76 & 4.32 & 0.13 & 11.90 & 0.004141 & 0.003755 & 0.072241 \\
\hline & Riau & 2009 & -1.87 & 4.28 & 0.38 & 1.43 & 0.004749 & 0.006082 & 0.184230 \\
\hline & & 2010 & 2.23 & 10.81 & 0.23 & 6.17 & 0.004625 & 0.005333 & 0.165720 \\
\hline & & 2011 & 3.24 & 1.72 & 1.71 & 3.32 & 0.004455 & 0.005805 & 0.190624 \\
\hline & & 2012 & 3.49 & 9.50 & 0.05 & 0.71 & 0.004739 & 0.005515 & 0.179508 \\
\hline
\end{tabular}




\begin{tabular}{|c|c|c|c|c|c|c|c|c|c|}
\hline NO & PROV. & THN & $\mathbf{Y}$ & POP & INV & INF & RI & EI & AI \\
\hline \multirow[t]{5}{*}{11} & \multirow[t]{5}{*}{ Jakarta } & 2008 & 4.47 & 0.90 & 0.27 & 11.11 & 0.014154 & 0.012780 & 0.543944 \\
\hline & & 2009 & 3.68 & 0.84 & 1.28 & 2.34 & 0.015532 & 0.019046 & 0.550342 \\
\hline & & 2010 & 5.09 & 4.17 & 0.53 & 6.21 & 0.015969 & 0.019255 & 0.559889 \\
\hline & & 2011 & 5.51 & -0.30 & 0.94 & 3.97 & 0.016098 & 0.019020 & 0.629952 \\
\hline & & 2012 & 5.34 & 3.16 & 0.77 & 1.47 & 0.017827 & 0.019657 & 0.622988 \\
\hline \multirow[t]{5}{*}{12} & \multirow[t]{5}{*}{ Jawa Barat } & 2008 & 3.98 & 1.46 & 0.68 & 10.23 & 0.024752 & 0.024431 & 0.156930 \\
\hline & & 2009 & 2.32 & 1.43 & 0.68 & 2.11 & 0.031010 & 0.034917 & 0.222726 \\
\hline & & 2010 & 4.28 & 3.74 & 2.05 & 4.53 & 0.030042 & 0.036849 & 0.250609 \\
\hline & & 2011 & 4.79 & 0.47 & 1.30 & 2.75 & 0.029941 & 0.036721 & 0.273066 \\
\hline & & 2012 & 4.60 & 3.29 & 1.20 & 1.76 & 0.032775 & 0.037544 & 0.275518 \\
\hline \multirow[t]{5}{*}{13} & \multirow[t]{5}{*}{ Jawa Tengah } & 2008 & 4.90 & 0.76 & 0.36 & 10.34 & 0.022969 & 0.024002 & 0.118582 \\
\hline & & 2009 & 4.98 & 0.73 & 0.66 & 3.19 & 0.026710 & 0.030258 & 0.201128 \\
\hline & & 2010 & 5.53 & -1.47 & 0.18 & 7.11 & 0.025462 & 0.030171 & 0.210909 \\
\hline & & 2011 & 5.12 & 3.44 & 0.55 & 2.87 & 0.025709 & 0.030711 & 0.205627 \\
\hline & & 2012 & 5.46 & -2.76 & 1.04 & 2.32 & 0.027588 & 0.030178 & 0.210155 \\
\hline \multirow[t]{5}{*}{14} & \multirow{5}{*}{$\begin{array}{l}\text { D.I. } \\
\text { Yogyakarta }\end{array}$} & 2008 & 3.65 & 0.99 & 0.00 & 9.88 & 0.003852 & 0.004187 & 0.120979 \\
\hline & & 2009 & 3.46 & 0.96 & 0.08 & 2.93 & 0.004211 & 0.004909 & 0.216443 \\
\hline & & 2010 & 3.94 & -1.27 & 0.02 & 7.38 & 0.003956 & 0.004915 & 0.220063 \\
\hline & & 2011 & 3.89 & 0.47 & 0.00 & 3.88 & 0.003872 & 0.004645 & 0.229174 \\
\hline & & 2012 & 4.06 & 1.64 & 0.59 & 1.63 & 0.004140 & 0.004623 & 0.237484 \\
\hline \multirow[t]{5}{*}{15} & \multirow[t]{5}{*}{ Jawa Timur } & 2008 & 4.83 & 0.54 & 0.45 & 8.73 & 0.026381 & 0.027122 & 0.145486 \\
\hline & & 2009 & 4.36 & 0.52 & 0.62 & 3.39 & 0.032228 & 0.037110 & 0.226808 \\
\hline & & 2010 & 6.02 & 0.51 & 1.04 & 7.33 & 0.032361 & 0.038452 & 0.236258 \\
\hline & & 2011 & 6.43 & 1.39 & 1.10 & 4.72 & 0.031510 & 0.036469 & 0.264953 \\
\hline & & 2012 & 6.53 & 0.02 & 2.15 & 1.56 & 0.033482 & 0.037790 & 0.254493 \\
\hline \multirow[t]{5}{*}{16} & \multirow[t]{5}{*}{ Banten } & 2008 & 2.74 & 1.90 & 1.42 & 13.91 & 0.006294 & 0.006014 & 0.194335 \\
\hline & & 2009 & 1.81 & 1.88 & 2.87 & 4.57 & 0.007258 & 0.007885 & 0.290652 \\
\hline & & 2010 & 3.30 & 8.68 & 3.41 & 6.18 & 0.007605 & 0.008854 & 0.304360 \\
\hline & & 2011 & 3.89 & 0.82 & 2.23 & 2.78 & 0.008308 & 0.009300 & 0.352104 \\
\hline & & 2012 & 3.74 & 4.87 & 2.40 & 2.09 & 0.009027 & 0.010048 & 0.350079 \\
\hline \multirow[t]{5}{*}{17} & \multirow[t]{5}{*}{ Bali } & 2008 & 3.51 & 1.04 & 0.06 & 9.25 & 0.005555 & 0.005323 & 0.139911 \\
\hline & & 2009 & 3.09 & 1.00 & 0.08 & 4.37 & 0.006663 & 0.007588 & 0.317872 \\
\hline & & 2010 & 3.73 & 9.57 & 0.47 & 8.10 & 0.006284 & 0.007317 & 0.346039 \\
\hline & & 2011 & 5.14 & 0.42 & 0.42 & 3.75 & 0.006217 & 0.007326 & 0.388829 \\
\hline & & 2012 & 5.33 & 4.16 & 3.70 & 2.65 & 0.006915 & 0.007800 & 0.384678 \\
\hline \multirow[t]{5}{*}{18} & \multirow{5}{*}{$\begin{array}{l}\text { Nusa } \\
\text { Tenggara } \\
\text { Barat }\end{array}$} & 2008 & 1.34 & 1.66 & 0.00 & 13.01 & 0.004208 & 0.004455 & 0.072299 \\
\hline & & 2009 & 10.90 & 1.61 & 0.00 & 3.14 & 0.005071 & 0.005824 & 0.114333 \\
\hline & & 2010 & 5.23 & 1.49 & 3.64 & 11.07 & 0.005309 & 0.006660 & 0.111534 \\
\hline & & 2011 & -4.09 & 2.34 & 0.09 & 6.38 & 0.005040 & 0.006101 & 0.155502 \\
\hline & & 2012 & -2.49 & -0.09 & 0.09 & 2.51 & 0.004998 & 0.005973 & 0.132819 \\
\hline \multirow[t]{5}{*}{19} & Nusa & 2008 & 2.48 & 1.92 & 0.00 & 10.90 & 0.005755 & 0.006377 & 0.030363 \\
\hline & Tengga & 2009 & 2.15 & 1.88 & 0.00 & 6.49 & 0.007153 & 0.009560 & 0.068663 \\
\hline & Timur & 2010 & 3.21 & 1.39 & 0.00 & 9.97 & 0.006245 & 0.008093 & 0.073262 \\
\hline & & 2011 & 3.79 & 2.22 & 0.00 & 4.32 & 0.006613 & 0.008113 & 0.074186 \\
\hline & & 2012 & 3.65 & 2.13 & 0.04 & 2.44 & 0.006589 & 0.008028 & 0.080200 \\
\hline 20 & Kalimantan & 2008 & 4.19 & 1.69 & 0.50 & 11.19 & 0.006094 & 0.006509 & 0.070909 \\
\hline & Barat & 2009 & 3.94 & 1.65 & 0.95 & 4.91 & 0.007199 & 0.008533 & 0.098868 \\
\hline & & 2010 & 4.58 & 1.78 & 1.94 & 8.52 & 0.006896 & 0.008675 & 0.111105 \\
\hline & & 2011 & 4.15 & 6.67 & 2.10 & 4.91 & 0.006673 & 0.008052 & 0.137057 \\
\hline & & 2012 & 4.04 & -4.55 & 3.75 & 3.69 & 0.006793 & 0.008093 & 0.137207 \\
\hline 21 & Kalimantan & 2008 & 4.04 & 1.43 & 2.08 & 11.65 & 0.005842 & 0.006462 & 0.047982 \\
\hline & Tengah & 2009 & 3.78 & 1.39 & 3.94 & 1.39 & 0.006776 & 0.008365 & 0.079010 \\
\hline & & 2010 & 4.71 & 6.05 & 8.24 & 9.49 & 0.006084 & 0.007515 & 0.088662 \\
\hline & & 2011 & 4.22 & 3.30 & 6.88 & 5.28 & 0.005927 & 0.006618 & 0.111838 \\
\hline
\end{tabular}




\begin{tabular}{|c|c|c|c|c|c|c|c|c|c|}
\hline NO & PROV. & THN & $\mathbf{Y}$ & POP & INV & INF & RI & EI & AI \\
\hline & & 2012 & 4.18 & 0.49 & 8.11 & 2.95 & 0.006042 & 0.006856 & 0.120635 \\
\hline \multirow[t]{5}{*}{22} & \multirow{5}{*}{$\begin{array}{l}\text { Kalimantan } \\
\text { Selatan }\end{array}$} & 2008 & 4.13 & 1.47 & 1.29 & 11.62 & 0.006027 & 0.006010 & 0.128558 \\
\hline & & 2009 & 3.27 & 1.44 & 1.69 & 3.86 & 0.007816 & 0.008693 & 0.144598 \\
\hline & & 2010 & 3.59 & 3.73 & 3.37 & 9.06 & 0.006921 & 0.008768 & 0.172348 \\
\hline & & 2011 & 4.07 & 1.68 & 3.11 & 3.98 & 0.007200 & 0.007951 & 0.195245 \\
\hline & & 2012 & 3.74 & 2.26 & 4.62 & 2.74 & 0.008262 & 0.007873 & 0.199267 \\
\hline \multirow[t]{5}{*}{23} & \multirow{5}{*}{$\begin{array}{l}\text { Kalimantan } \\
\text { Timur }\end{array}$} & 2008 & 1.01 & 2.31 & 0.09 & 12.69 & 0.018253 & 0.018086 & 0.083520 \\
\hline & & 2009 & -1.76 & 2.27 & 0.03 & 4.06 & 0.017660 & 0.027196 & 0.153788 \\
\hline & & 2010 & 1.37 & 12.27 & 2.45 & 7.00 & 0.018263 & 0.021900 & 0.142844 \\
\hline & & 2011 & 1.32 & 1.61 & 1.68 & 6.23 & 0.020314 & 0.019467 & 0.167403 \\
\hline & & 2012 & 1.27 & 6.37 & 1.40 & 2.24 & 0.021404 & 0.021531 & 0.168280 \\
\hline \multirow[t]{5}{*}{24} & \multirow{5}{*}{$\begin{array}{l}\text { Sulawesi } \\
\text { Utara }\end{array}$} & 2008 & 9.15 & 0.97 & 0.15 & 9.71 & 0.003983 & 0.004065 & 0.059615 \\
\hline & & 2009 & 6.63 & 0.94 & 0.15 & 2.31 & 0.005231 & 0.005945 & 0.081422 \\
\hline & & 2010 & 5.87 & 1.87 & 0.26 & 6.28 & 0.005069 & 0.006166 & 0.089296 \\
\hline & & 2011 & 6.09 & 3.20 & 0.79 & 0.67 & 0.004848 & 0.005829 & 0.099603 \\
\hline & & 2012 & 6.58 & -0.62 & 1.44 & 2.89 & 0.004631 & 0.005514 & 0.111849 \\
\hline \multirow[t]{5}{*}{25} & \multirow{5}{*}{$\begin{array}{l}\text { Sulawesi } \\
\text { Tengah }\end{array}$} & 2008 & 5.47 & 1.76 & 0.00 & 10.40 & 0.004334 & 0.004438 & 0.045565 \\
\hline & & 2009 & 5.71 & 1.72 & 0.00 & 5.73 & 0.004673 & 0.005612 & 0.083565 \\
\hline & & 2010 & 6.73 & 6.24 & 0.41 & 6.40 & 0.004776 & 0.005989 & 0.090396 \\
\hline & & 2011 & 7.22 & 1.23 & 5.91 & 4.47 & 0.004679 & 0.005716 & 0.097085 \\
\hline & & 2012 & 7.38 & 2.78 & 1.18 & 2.29 & 0.004664 & 0.005630 & 0.105475 \\
\hline \multirow[t]{5}{*}{26} & \multirow{5}{*}{$\begin{array}{l}\text { Sulawesi } \\
\text { Selatan }\end{array}$} & 2008 & 6.23 & 1.36 & 1.30 & 11.79 & 0.009962 & 0.010868 & 0.091563 \\
\hline & & 2009 & 5.14 & 1.33 & 1.14 & 3.24 & 0.011300 & 0.014063 & 0.142128 \\
\hline & & 2010 & 7.01 & 1.60 & 2.73 & 6.82 & 0.011139 & 0.013343 & 0.144996 \\
\hline & & 2011 & 6.34 & 2.67 & 2.90 & 2.87 & 0.011071 & 0.013103 & 0.155489 \\
\hline & & 2012 & 7.17 & -0.34 & 1.45 & 2.43 & 0.011016 & 0.012909 & 0.163988 \\
\hline \multirow[t]{5}{*}{27} & \multirow{5}{*}{$\begin{array}{l}\text { Sulawesi } \\
\text { Tenggara }\end{array}$} & 2008 & 4.85 & 2.14 & 0.00 & 15.28 & 0.004030 & 0.004276 & 0.055134 \\
\hline & & 2009 & 5.35 & 2.09 & 0.00 & 4.60 & 0.004855 & 0.005952 & 0.065007 \\
\hline & & 2010 & 6.09 & 5.40 & 0.07 & 3.87 & 0.004496 & 0.005557 & 0.082973 \\
\hline & & 2011 & 6.55 & 1.53 & 0.18 & 5.09 & 0.004426 & 0.005348 & 0.075120 \\
\hline & & 2012 & 8.02 & 2.82 & 2.48 & 3.57 & 0.004615 & 0.005396 & 0.080427 \\
\hline \multirow[t]{5}{*}{28} & \multirow[t]{5}{*}{ Gorontalo } & 2008 & 5.15 & 1.24 & 0.00 & 9.20 & 0.001901 & 0.002007 & 0.036774 \\
\hline & & 2009 & 5.09 & 1.21 & 0.00 & 4.35 & 0.002248 & 0.002818 & 0.083271 \\
\hline & & 2010 & 5.40 & 5.71 & 0.21 & 7.43 & 0.002106 & 0.002579 & 0.085449 \\
\hline & & 2011 & 5.87 & 2.59 & 0.13 & 4.08 & 0.002028 & 0.002542 & 0.080724 \\
\hline & & 2012 & 5.95 & 1.93 & 1.59 & 2.85 & 0.001943 & 0.002391 & 0.099293 \\
\hline \multirow[t]{5}{*}{29} & \multirow[t]{5}{*}{ Sulbar } & 2008 & 8.96 & 1.53 & 0.00 & 11.66 & 0.001725 & 0.001906 & 0.026399 \\
\hline & & 2009 & 3.15 & 1.50 & 0.00 & 1.78 & 0.002015 & 0.002549 & 0.045733 \\
\hline & & 2010 & 9.11 & 10.59 & 7.65 & 5.12 & 0.000895 & 0.001144 & 0.023001 \\
\hline & & 2011 & 8.20 & 1.45 & 1.70 & 4.91 & 0.001900 & 0.002325 & 0.054674 \\
\hline & & 2012 & 6.92 & 3.97 & 1.59 & 0.84 & 0.001906 & 0.002266 & 0.061451 \\
\hline \multirow[t]{5}{*}{30} & Maluku & 2008 & 1.23 & 1.44 & 0.00 & 9.34 & 0.003237 & 0.003528 & 0.027309 \\
\hline & & 2009 & 2.46 & 1.42 & 0.00 & 6.48 & 0.003898 & 0.004974 & 0.059893 \\
\hline & & 2010 & 3.65 & 14.48 & 0.00 & 8.78 & 0.003891 & 0.004834 & 0.053409 \\
\hline & & 2011 & 4.13 & 2.68 & 0.00 & 2.85 & 0.003646 & 0.004430 & 0.057826 \\
\hline & & 2012 & 5.85 & 3.14 & 0.03 & 7.72 & 0.003488 & 0.004157 & 0.060055 \\
\hline 31 & Maluku Utara & 2008 & 3.24 & 1.62 & 0.00 & 11.25 & 0.002841 & 0.003108 & 0.019527 \\
\hline & & 2009 & 3.44 & 1.60 & 0.00 & 3.88 & 0.003112 & 0.004336 & 0.051693 \\
\hline & & 2010 & 5.47 & 6.47 & 0.00 & 5.32 & 0.002760 & 0.003522 & 0.058431 \\
\hline & & 2011 & 4.02 & 2.51 & 0.22 & 4.52 & 0.002929 & 0.003395 & 0.067899 \\
\hline & & 2012 & 4.33 & 3.60 & 4.63 & 1.68 & 0.002878 & 0.003542 & 0.073085 \\
\hline 32 & Papua & 2008 & 3.93 & 1.95 & 2.11 & 20.51 & 0.005295 & 0.005887 & 0.010637 \\
\hline & Barat & 2009 & 9.51 & 1.90 & 0.23 & 7.52 & 0.006885 & 0.008325 & 0.028472 \\
\hline & & 2010 & 24.00 & 2.23 & 0.66 & 4.68 & 0.006500 & 0.007921 & 0.030776 \\
\hline
\end{tabular}




\begin{tabular}{|l|l|r|r|r|r|r|r|r|c|}
\hline NO & PROV. & THN & Y & POP & INV & \multicolumn{1}{|c|}{ INF } & RI & EI & AI \\
\hline & & 2011 & 23.67 & 1.84 & 3.81 & 3.64 & 0.006057 & 0.007017 & 0.028598 \\
& & 2012 & 12.88 & 6.13 & 0.13 & 2.37 & 0.005738 & 0.006913 & 0.032838 \\
\hline 33 & Papua & 2008 & -6.21 & 2.03 & 0.00 & 12.55 & 0.013631 & 0.014730 & 0.019325 \\
& & 2009 & 15.27 & 1.99 & 0.00 & 1.92 & 0.016247 & 0.018608 & 0.043888 \\
& & 2010 & -8.05 & 35.08 & 0.06 & 4.48 & 0.015417 & 0.019049 & 0.039601 \\
& & 2011 & -7.21 & 5.93 & 0.06 & 3.40 & 0.014701 & 0.017523 & 0.035176 \\
& & 2012 & -0.92 & 5.48 & 0.06 & 0.24 & 0.014030 & 0.017050 & 0.051592 \\
\hline
\end{tabular}

\section{LAMPIRAN II \\ Hasil Uji Statistik F}

Redundant Fixed Effects Tests

Pool: DF_PROV

Test cross-section fixed effects

\begin{tabular}{lrrr}
\hline \hline Effects Test & Statistic & d.f. & Prob. \\
\hline \hline Cross-section F & 4.706422 & $(32,126)$ & 0.0000 \\
Cross-section Chi-square & 129.741222 & 32 & 0.0000 \\
\hline \hline
\end{tabular}

Cross-section fixed effects test equation:

Dependent Variable: Y?

Method: Panel Least Squares

Date: 09/28/15 Time: 06:28

Sample: 20082012

Included observations: 5

Cross-sections included: 33

Total pool (balanced) observations: 165

\begin{tabular}{crrrr}
\hline \hline Variable & Coefficient & Std. Error & t-Statistic & Prob. \\
\hline \hline C & 5.849477 & 0.854183 & 6.848041 & 0.0000 \\
POP? & -0.241982 & 0.078146 & -3.096539 & 0.0023 \\
INV? & 0.412552 & 0.185586 & 2.222973 & 0.0276 \\
INF? & -0.121906 & 0.080119 & -1.521568 & 0.1301 \\
R? & 247.7332 & 300.4467 & 0.824550 & 0.4109 \\
E1? & -263.0633 & 262.5500 & -1.001955 & 0.3179 \\
A1? & -1.657272 & 2.905443 & -0.570403 & 0.5692 \\
\hline \hline R-squared & 0.110687 & Mean dependent var & 4.193571 \\
Adjusted R-squared & 0.076915 & S.D. dependent var & 3.783014 \\
S.E. of regression & 3.634617 & Akaike info criterion & 5.460383 \\
Sum squared resid & 2087.250 & Schwarz criterion & 5.592150 \\
Log likelihood & -443.4816 & Hannan-Quinn criter. & 5.513872 \\
F-statistic & 3.277530 & Durbin-Watson stat & 1.022246 \\
Prob(F-statistic) & 0.004578 & & & \\
\hline \hline
\end{tabular}




\section{LAMPIRAN III \\ Hasil Uji Hausman}

Correlated Random Effects - Hausman Test

Pool: DF_PROV

Test cross-section random effects

\begin{tabular}{|c|c|c|c|c|}
\hline Test Summary & & $\begin{array}{l}\text { Chi-Sq. } \\
\text { Statistic }\end{array}$ & Chi-Sq. d.f. & Prob. \\
\hline Cross-section random & & 7.062177 & 6 & 0.3151 \\
\hline \multicolumn{5}{|c|}{ Cross-section random effects test comparisons: } \\
\hline Variable & Fixed & Random & Var(Diff.) & Prob. \\
\hline POP? & -0.109431 & -0.143563 & 0.000340 & 0.0642 \\
\hline INV? & 0.341885 & 0.357353 & 0.009556 & 0.8743 \\
\hline \multirow[t]{2}{*}{ INF? } & -0.164957 & -0.157816 & 0.001586 & 0.8577 \\
\hline & & \multicolumn{3}{|c|}{77158.53117} \\
\hline $\mathrm{R}$ ? & 509.639270 & 273.801336 & 3 & 0.3959 \\
\hline \multicolumn{5}{|c|}{-} \\
\hline E1? & 263.478762 & \multicolumn{2}{|c|}{$-275.7707503981 .462181$} & 0.8455 \\
\hline A1? & -6.709403 & -1.962564 & 78.905372 & 0.5931 \\
\hline
\end{tabular}

Cross-section random effects test equation:

Dependent Variable: Y?

Method: Panel Least Squares

Date: 09/28/15 Time: 06:29

Sample: 20082012

Included observations: 5

Cross-sections included: 33

Total pool (balanced) observations: 165

\begin{tabular}{crrrr}
\hline \hline Variable & Coefficient & Std. Error & t-Statistic & Prob. \\
\hline \hline C & 4.098217 & 2.771538 & 1.478680 & 0.1417 \\
POP? & -0.109431 & 0.068623 & -1.594669 & 0.1133 \\
INV? & 0.341885 & 0.208467 & 1.639993 & 0.1035 \\
INF? & -0.164957 & 0.075546 & -2.183523 & 0.0308 \\
R? & 509.6393 & 366.1681 & 1.391818 & 0.1664 \\
E1? & -263.4788 & 213.5268 & -1.233938 & 0.2195 \\
A1? & -6.709403 & 9.898228 & -0.677839 & 0.4991 \\
& Effects Specification & & \\
\hline \hline & & & & \\
\hline \hline Cross-section fixed (dummy variables) & & & \\
\hline \hline & & & & \\
R-squared & 0.594898 & Mean dependent var & 3.193571 \\
Adjusted R-squared & 0.472724 & S.D. dependent var & 3.783014 \\
S.E. of regression & 2.746988 & Akaike info criterion & 5.061951 \\
Sum squared resid & 950.7890 & Schwarz criterion & 5.796084 \\
Log likelihood & -378.6110 & Hannan-Quinn criter. & 5.359961 \\
F-statistic & 4.869282 & Durbin-Watson stat & 2.242718 \\
Prob(F-statistic) & 0.000000 & & \\
\hline \hline
\end{tabular}




\section{LAMPIRAN IV \\ Hasil Estimasi Regresi}

Dependent Variable: Y?

Method: Pooled EGLS (Cross-section random effects)

Date: 09/27/15 Time: 17:34

Sample: 20082012

Included observations: 5

Cross-sections included: 33

Total pool (balanced) observations: 165

Swamy and Arora estimator of component variances

\begin{tabular}{crrrr}
\hline \hline Variable & Coefficient & Std. Error & t-Statistic & Prob. \\
\hline \hline C & 5.792767 & 1.032575 & 5.610022 & 0.0000 \\
POP? & -0.143563 & 0.066099 & -2.171945 & 0.0314 \\
INV? & 0.357353 & 0.184127 & 1.940796 & 0.0541 \\
INF? & -0.157816 & 0.064199 & -2.458220 & 0.0150 \\
RI? & 273.8013 & 238.5803 & 1.147628 & 0.2529 \\
EI? & -275.7708 & 203.9907 & -1.351879 & 0.1783 \\
AI? & -1.962564 & 4.366869 & -0.449421 & 0.6537
\end{tabular}

Random Effects (Cross)

\begin{tabular}{cr} 
_ACEH--C & -4.592521 \\
_SUMUT--C & 0.698338 \\
_SUMBAR--C & 0.228928 \\
_RIAU--C & -2.460414 \\
_JAMBI--C & 0.342739 \\
_SUMSEL--C & -0.548138 \\
_BENGKULU--C & 0.067649 \\
_LAMPUNG--C & 0.369261 \\
_BABEL--C & -1.280809 \\
_KEPRI--C & -1.621492 \\
_JAKARTA--C & 1.210314 \\
_JABAR--C & 0.381397 \\
_JATENG--C & 1.102969 \\
_YOGYA--C & -0.444249 \\
_JATIM--C & 1.594018 \\
_BANTEN--C & -1.048761 \\
_BALI--C & 0.172698 \\
_NTB--C & -1.632410 \\
_NTT--C & -0.647166 \\
_KALBAR--C & -0.351700 \\
_KALTENG--C & -1.496507 \\
_KALSEL--C & -0.977118 \\
_KALTIM--C & -2.237063 \\
_SULUT--C & 1.686953 \\
_SULTENG--C & 1.504116 \\
_SULSEL--C & 1.414198 \\
_SULTRA--C & 1.568957 \\
GORONTALO--C & 0.854989 \\
_SULBAR--C & 1.732778 \\
_MALUKU--C & -0.189019 \\
_MALUT--C & -0.353249 \\
_PAPBAR--C & 8.311125 \\
_PAPUA--C & -3.360811 \\
\hline
\end{tabular}

Effects Specification

S.D. Rho

\begin{tabular}{lll}
\hline \hline Cross-section random & 2.390948 & 0.4310 \\
Idiosyncratic random & 2.746988 & 0.5690
\end{tabular}


Weighted Statistics

\begin{tabular}{|c|c|c|c|}
\hline R-squared & 0.098037 & Mean dependent var & 1.916515 \\
\hline Adjusted R-squared & 0.063785 & S.D. dependent var & 2.848551 \\
\hline S.E. of regression & 2.756206 & Sum squared resid & 1200.274 \\
\hline F-statistic & 2.862251 & Durbin-Watson stat & 1.771113 \\
\hline Prob(F-statistic) & 0.011279 & & \\
\hline \multicolumn{4}{|c|}{ Unweighted Statistics } \\
\hline R-squared & 0.099636 & Mean dependent var & 4.193571 \\
\hline Sum squared resid & 2113.186 & Durbin-Watson stat & 1.005980 \\
\hline
\end{tabular}

